\title{
Prevalence and Incidence of Cassava (Manihot esculenta) Brown Leaf Spot Disease Caused by Cercospora heningsii in Macuata Province, Vanua Levu, Fiji
}

\author{
Rahul Ravneel Prasad ${ }^{1}$, Mohseen Riaz Ud Dean ${ }^{2}$, Bradley Alungo ${ }^{1} \&$ Vinal Vishal Chand ${ }^{1}$ \\ ${ }^{1}$ University of the South Pacific, Laucala Campus, Suva, Fiji Islands \\ ${ }^{2}$ University of Fiji, Samabula Campus, Suva, Fiji Islands \\ Correspondence: Rahul Ravneel Prasad, University of the South Pacific, Laucala Campus, Suva, Fiji Islands. \\ E-mail: rahulravneelprasad12@gmail.com
}

Received: January 20, 2020

Accepted: June 23, $2021 \quad$ Online Published: July 15, 2021

doi:10.5539/jas.v13n8p91

URL: https://doi.org/10.5539/jas.v13n8p91

\begin{abstract}
Cassava (Manihot esculenta Crantz) is a crop of many values in the tropical and subtropical regions of the globe. In Fiji, cassava is cultivated on vast acres of land but, the yield obtained is relatively lower because of many constraints, including the prevalence of diseases caused by the different pathogens. Among various pathogens responsible for a lower yield, the cassava brown leaf spot disease caused by Cercospora heningsii is responsible for causing enormous annual losses of cassava in tropical and subtropical regions. Because there is very little information regarding the association of the brown leaf spot disease and cassava in the country, the present study using survey as research instrument endeavors to determine the disease incidence and prevalence of brown leaf spot disease in the cassava fields of three villages (Mani Road, Boca, and Anuve) in the Bulileka area of the Macuata province in Vanua Levu, Fiji. The study found that brown leaf spot disease prevailed $(100 \%)$ in all three villages. The percentage of disease incidence ranged from $36.4 \%$ to $42.9 \%$. The maximum incidence (42.9\%) of cassava brown leaf spot disease was found in Anuve village, followed by Mani Road village (38.2\%), with the lowest disease incidence recorded for Boca village (36.4\%).
\end{abstract}

Keywords: prevalence, incidence, brown leaf spot, cassava disease, Cercospora heningsii, Fiji Islands

\section{Introduction}

Cassava (Manihot esculenta Crantz) is a shrubby perennial plant of the family Euphorbiaceae that typically grows from one to three meters (3-10 feet) in height (Thresh et al., 1998). Among the 28 known species of the Euphorbiaceae family, cassava is the only edible crop, and its tuberous roots are a good source of carbohydrates (Katz \& Weaver, 2003). Cassava is a key staple food in several countries (African, South American, Asian, and the Pacific) and has the highest production potential calories per hectare per day among tropical crops (Alicai et al., 2007). In Fiji, cassava is grown by small-scale farmers for subsistence use and its cultivation often also constitutes an essential source of income in rural and marginal areas.

However, cassava growth and yield are affected by biotic constraints (Hahn et al., 1989), among which pathogenic diseases are of critical importance. In Fiji, a primary fungal disease that affects cassava production is the brown leaf spot disease caused by Cercospora heningsii (Tsatsia \& Jackson, 2010). The symptoms of this disease appear as small brown spots with dark borders on the upper surfaces of the leaves (Msikita et al., 2000). On the underside of the leaf, the disease spot displays greyish color with less distinct borders, with minor veins crossing the disease spots and appearing as black necrotic lines. The center of the disease spot is dry, looks cracked, and appears as if it will suddenly fall off (Tsatsia \& Jackson, 2010).

The cassava leaves are the core source of assimilation for dry matter production. An increase in brown leaf spot disease reduces the photosynthetic area and capabilities of the plant (Hahn \& Hozyo, 1984). A severe brown leaf spot infection results in total defoliation and hence failure (Alabi \& Waliyar, 2004). Similarly, many of the leaf spot-causing organisms can kill the host partially or fully, not only by direct destruction of the tissues but also by systemic dispersal of toxic substances far beyond the original areas of infection (Bilgrami \& Dube, 1976). 
The amount of disease is measured as the proportion of the crop population (counted as individual plants or branches or leaves) that is infected (disease incidence) or the percentage of the area of the plant that is affected (disease severity). Several studies relating to the cassava brown leaf spot disease exist in many tropical and subtropical countries (Pei et al., 2014; Powbunthorn et al., 2012; Banito et al., 2007). However, there are few or no studies conducted to ascertain the incidence and prevalence of the disease on cassava plants in Fiji. Therefore, the present study was conducted to determine the incidence and prevalence of the disease in three villages at the Macuata Province of Fiji.

\section{Methods and Materials}

\subsection{Study Area}

A survey of cassava fields located in three selected localities of the vegetable-growing villages in the Macuata Province of Labasa was conducted in the year 2014. The sites were selected based on the following factors. First, the villages could be easily accessed by the researchers. And second, they were selected based on experiences and observations shared by local farmers that the disease was becoming widespread in their cassava fields.

\subsection{Map of Study Area}

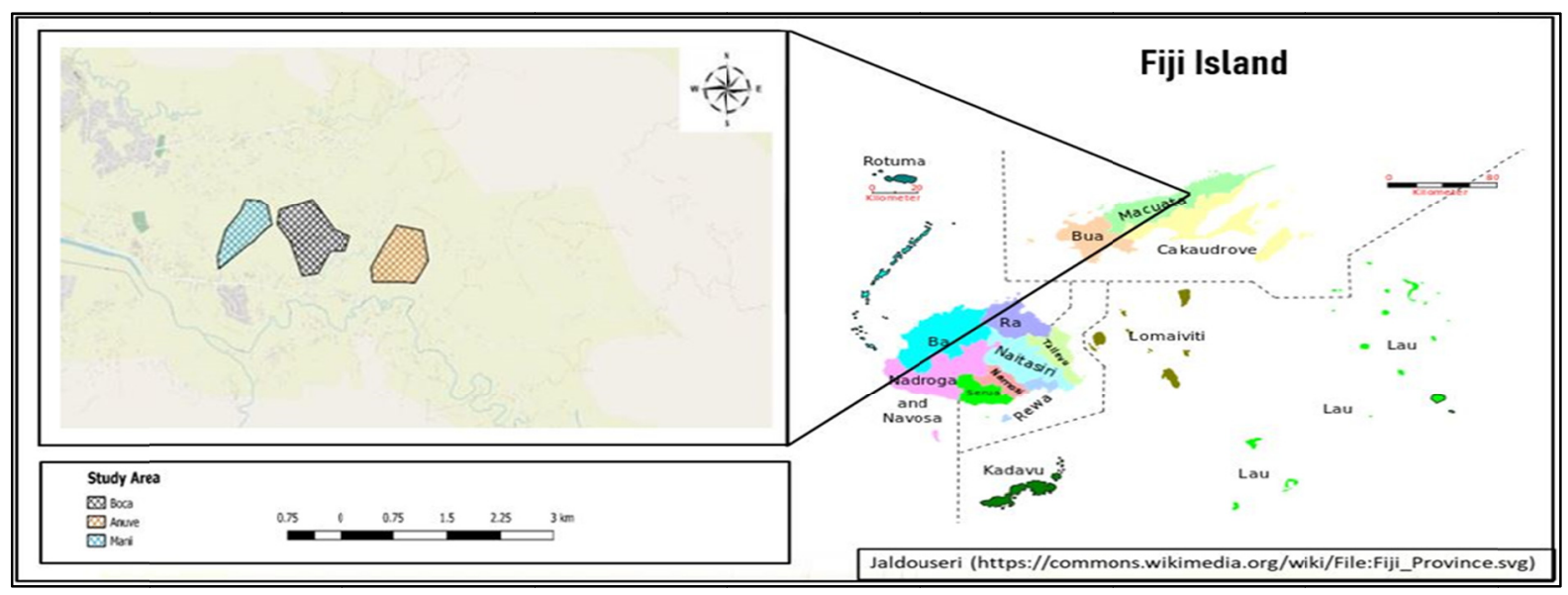

Figure 1. Map of study area

Note. Three villages (area) selected for this study are indicated using closed borders.

\subsection{Data Collection}

To determine the prevalence and incidence of brown leaf spot disease, three cassava fields, each from Mani Road, Boca, and Anuve, were selected using a simple random sampling (SRS) approach (Banito et al., 2007). After randomly selecting the cassava fields, the study adopted the data collection approach ( $\mathrm{Z}$ transect method) used by Hussain et al. (2012). From each cassava field, 20 cassava plants were selected to determine the incidence of the disease. To detect the disease, cassava leaves were inspected, and observations made were scrutinized against information such as disease characteristics and symptoms found in the Pacific Pests and Pathogens Fact Sheets by Tsatsia and Jackson (2010).

\subsection{Incidence of Disease}

Disease incidence is commonly used to refer to the number of a specific part of a plant that is affected by the disease. The specific part of the plant can be its roots, stem, and leaves (Campbell \& Neher, 1994). For this study, the incidence of the disease is based on its visibility on leaves. Disease incidences (\%) are calculated by taking the number of leaves infected divided by the total number of leaves being observed and multiplied by 100 (Equation 1).

$$
\text { Incidence }(\%)=\frac{\text { Total No. of infected leaves }}{\text { Total No. of leaves observed }} \times 100
$$

\subsection{Prevalence of Disease}

Prevalence of the disease is defined by the incidence of the disease visible on plants in a particular geographic area (Nutter et al., 1991; Paparu et al., 2018). The disease prevalence was calculated by taking the number of 
fields displaying incidence of the disease divided by the total number of fields assessed and multiplied by 100 (Mounde et al., 2009).

\section{Results and Discussion}

\subsection{Detection and Inspection}

After conducting the inspections, we confirmed that the brown leaf spot disease was present in the cassava fields of the three villages. The disease was mostly found on mature and old plants but rarely on young plants (Figure 2). The characteristics of the disease in the fields was matched against the descriptions and facts outlined by Tsatsia and Jackson (2010) in the Pacific Pests and Pathogens Fact Sheets to further confirm its presence.

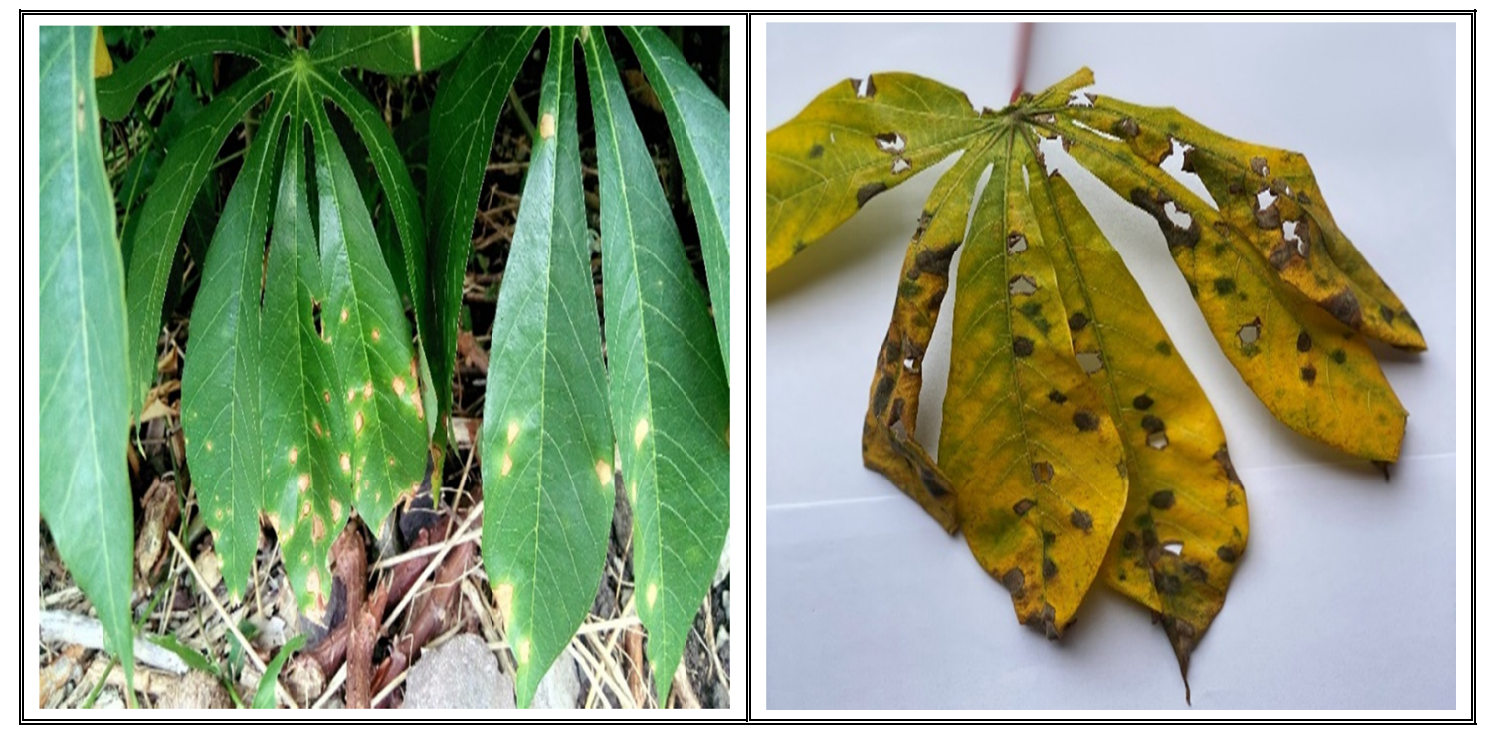

Figure 2. Cassava leaves with visible brown spots caused by Cercospora heningsii

\subsection{Incidence of the Disease}

Disease incidence was calculated using Equation 1 for the three villages: Mani Road, Boca, and Anuve. The calculations showed that Anuve village had the highest incidence (42.9\%) of cassava brown leaf spot disease, followed by Mani Road village (38.2\%). The lowest incidence of the disease was found at Boca village (36.4\%) (Table 1).

Table 1. Summary of cassava brown leaf spot disease incidence (\%) in three villages of Bulileka

\begin{tabular}{lllll}
\hline Village & $\begin{array}{l}\text { Total No. of cassava } \\
\text { plants surveyed }\end{array}$ & $\begin{array}{l}\text { Total No. of } \\
\text { Leaves inspected }\end{array}$ & $\begin{array}{l}\text { Total No. of infected } \\
\text { leaves inspected }\end{array}$ & \% disease incidence \\
\hline Anuve & 20 & 35 & 15 & $42.9 \%$ \\
Mani road & 20 & 34 & 13 & $38.2 \%$ \\
Boca & 20 & 33 & 12 & $36.4 \%$ \\
\hline Average & & & $\mathbf{3 9 . 2 \%}$ \\
\hline
\end{tabular}

Generally, lower severity and incidence of cassava brown leaf spot disease may be due to climatic conditions (Takatsu et al., 1978). Our results overall indicated a high incidence of the disease for the three villages. However, when we compare the three villages, there is minimal deviation. Higher disease incidence may be due to the continuous introduction of infected planting materials brought and utilized by farmers from the infected areas of the farm (Banito et al., 2007). In addition, a high incidence of cassava brown leaf spot disease may also be attributed to the cultivation of a single crop. Hiddink et al. (2005) reported that continuous cropping of one specific crop leads to increased disease incidence, often caused by soil-borne and other plant pathogens. Despite showing an insignificant variation of disease incidence within the three villages, some parameters may have 
influenced the disease incidence in these three villages to vary. Banito et al. (2007) reports that environmental conditions such as temperature, humidity, soil type, soil moisture, and cropping patterns are important parameters that influence the incidence of this disease.

Although we have observed higher disease incidence in all three villages, the percentage of disease incidence is below $50 \%$, meaning that more than $50 \%$ of the cassava plants are unaffected by the brown leaf spot disease, which explains why the Crop Farmer's Guide for Farmers formulated by the Ministry of Agriculture, Government of Fiji indicated that there is no significant disease that threatens cassava in Fiji (Fiji Government, 2015)

\subsection{Prevalence of Cassava Brown Leaf Spot Disease}

The prevalence of cassava brown leaf spot disease for the three villages was calculated using Equation 2. Results reveal a $100 \%$ disease prevalence for all the three villages (Table 2).

Table 2. Summary of cassava brown leaf spot disease prevalence (\%) in three villages of Bulileka

\begin{tabular}{llll}
\hline Village & Number of cassava fields & Number of cassava field infected & \% disease prevalence \\
\hline Anuve & 3 & 3 & $100 \%$ \\
Mani road & 3 & 3 & $100 \%$ \\
Boca & 3 & 3 & $100 \%$ \\
\hline Average & & $\mathbf{1 0 0} \%$ \\
\hline
\end{tabular}

High disease prevalence can be attributed to the susceptibility of cassava plants to the disease and the availability of a conducive climate for the disease to proliferate. For example, its prevalence in the study areas can be attributed to weather parameters such as the wind (moderate to high), which all three villages experience every day. In their study, Pelczar et al. (2020) and Tsatsia and Jackson (2010) found that wind was responsible for carrying disease spores across fields and/or from one field to another, and these spores infected cassava plants. In addition, because of tropical climate that Fiji enjoys, the study areas are also exposed to high humidity. Garcia-Guzman et al. (2016) write that humidity also increases the prevalence of the disease in the fields. Therefore, a study as such helps validate the many reports that say that the brown leaf spot disease could be prevalent around the globe where cassava grows (Pei et al., 2014; Powbunthorn et al., 2012; Banito et al., 2007), as we have seen in the case of Fiji for the villages understudy.

\subsection{Implication of Study, Limitation, and Further Studies}

The impacts of the cassava brown leaf spot disease on cassava yield is widely reported (Elegba et al., 2013; Tsatsia \& Jackson, 2010; Otim-Nape et al., 1997; Terry \& Hahn, 1980; Terry \& Oyekan, 1976). High disease incidence and prevalence and as well improper controls and management by the farmers can lead to yield losses if left unattended. Loss of yield will not only threaten food security but also income security in the villages of Mani Road, Boca, and Anuve, and the same can be said for other villages in Fiji where cassava is cultivated and may also be victims of the disease but are unaware of it. Furthermore, since the current climate of Fiji (Australia Bureau of Meteorology and CSIRO, 2014) is conducive for its proliferation (Tsatsia \& Jackson, 2010), we suspect that other parts of Fiji may be facing similar issues.

The limitation of this study is that it does not measure the climatic conditions of the study area for supplementary explanations of the variation in incidence, and the prevalence of the disease at the Mani Road, Boca, and Anuve villages. Also, the number of study sites and the total number of plants selected are too small to determine the overall incidence and prevalence of cassava brown leaf spot disease for the whole of Fiji. However, this can be done by increasing the number of study sites and the selection of reasonable representative sample of plants. Further studies can be undertaken to determine disease severity, impacts on yield, and its management. Also, it will be worthy to evaluate the current and future effects of climate change on disease incidence, severity, prevalence, and its implications on food and income security of local cassava farmers in Fiji.

\section{Conclusion}

Cassava brown leaf spot disease was prevalent in this study, 100 percent for all three villages, while the disease incidence varied across the three villages. Cassava plants showed extremely severe brown leaf spot symptoms in the cassava fields, raising the fear of high yield losses. Therefore, it is essential to conduct regular inspection and monitoring of cassava brown leaf spot disease to ensure the application of correct disease management strategies, and for successfully increasing crop yields. 


\section{Disclaimer}

This paper represents the views of the authors and not that of their employers.

\section{References}

Alabi, O., \& Waliyar, F. (2004). Yield loss due to late leafspot in sex groundnut varieties at Samaru in Northern Nigeria. Nig. J. Bot., 17, 29-32.

Alicai, T., Omongo, C. A., Maruthi, M. N., Hillocks, R. J., Baguma, Y., Kawuki, R., ... Colvin, J. (2007). Re-emergence of Cassava Brown Streak Disease in Uganda. Plant Disease, 91, 1-24. https://doi.org/ 10.1094/PD-91-0024

Alves, A. A. C. (2002). Cassava botany and physiology. Cassava: Biology, Production and Utilization, 1, 67-89. https://doi.org/10.1079/9780851995243.0067

Australia Bureau of Meteorology and CSIRO. (2014). Climate Variability, Extremes and Change in the Western Tropical Pacific: New Science and Updated Country Reports. Pacific-Australia Climate Change Science and Adaptation Planning Program Technical Report, Australia Bureau of Meteorology and Commonwealth Scientific and Industrial Research Organization, Melbourne, Australia.

Banito, A., Verdier, V., Kpémoua, K. E., \& Wydra, K. (2007). Assessment of major cassava diseases in Togo in relation to agronomic and environmental characteristics in a systems approach. African Journal of Agricultural Research, 2(9), 418-428.

Bilgrami, K. S., \& Dube, H. C. (1976). A textbook of modern plant pathology (p. 344). Vikas Publishing House, PVT Ltd, New Delhi.

Campbell, C. L., \& Neher, D. A. (1994). Estimating disease severity and incidence. Epidemiology and management of root diseases (pp. 117-147). Springer, Berlin, Heidelberg. https://doi.org/10.1007/ 978-3-642-85063-9_5

Elegba, W., Appiah, A. S., Azu, E., Afful, N., Agbemavor, W. K., Agyei-Amponsah, J., \& Danso, K. E. (2013). Effect of mosaic virus diseases on dry matter content and starch yield of five cassavas (Manihot esculenta Crantz) accessions in Ghana. African Journal of Biotechnology, 12(27). https://doi.org/10.5897/ AJB12.2958

El-Sharkawy, M. A. (2004). Cassava biology and physiology. Plant Molecular Biology, 56(4), $481-501$. https://doi.org/10.1007/s11103-005-2270-7

García-Guzmán, G., Trejo, I., Acosta-Calixto, I., \& Sánchez-Coronado, M. (2016). Environmental factors associated with disease incidence in plant species from a Mexican seasonal tropical dry forest. The Journal of the Torrey Botanical Society, 143(3), 254-264. https://doi.org/10.3159/TORREY-D-15-00055.1

Gashaw, G., Alemu, T., \& Tesfaye, K. (2014). Evaluation of disease incidence and severity and yield loss of finger millet varieties and mycelial growth inhibition of Pyricularia grisea isolates using biological antagonists and fungicides in vitro condition. Journal of Applied Biosciences, 73, 5883-5901.

Hahn, S. K., \& Hozyo, Y. (1984). Sweet potato. In P. R. Goldworthy, \& N. M. Fisher (Eds.), The physiology of tropical field crops (pp. 551-567). John Wiley and Sons Ltd., New York.

Hahn, S. K., John, C., Isoba, C., \& Ikotun, T. (1989). Resistance breeding in root crops at the International Institute of Tropical Agriculture (IITA), Ibadan, Nigeria. Crop Protection, 8, 147-168. https://doi.org/ 10.1016/0261-2194(89)90022-7

Hiddink, G. A., Termorshuizen, A. J., Raaijmakers, J. M., \& van Bruggen, A. H. (2005). Effect of mixed and single crops on disease suppressiveness of soils. Phytopathology, 95(11), 1325-1332. https://doi.org/ 10.1094/PHYTO-95-1325

Hussain, M. A., Mukhtar, T. A. R. I. Q., Kayani, M. Z., Aslam, M. N., \& Haque, M. I. (2012). A survey of okra (Abelmoschus esculentus) in the Punjab province of Pakistan for the determination of prevalence, incidence and severity of root-knot disease caused by Meloidogyne spp. Pak. J. Bot, 44(6), 2071-2075.

Katz, S. H., \& Weaver, W. W. (2003). Encyclopedia of Food and Culture. New York: Schribner.

Legg, J. P., \& Raya, M. D. (1998). Survey of cassava virus diseases in Tanzania. International Journal of Pest Management, 44, 17-23. https://doi.org/10.1080/096708798228473

Mounde, L. G., Ateka, E. M., Kihurani, A. W., Wasilwa, L., \& Thuranira, E. G. (2009). Occurrence and distribution of citrus gummosis (Phytophthora spp.) in Kenya. Afr. J. Horticultural Sci., 2, 56-68 
Msikita, W., James, B., Nnodu, E., Legg, J., Wydra, K., \& Ogbe, F. (2000). Disease control in cassava farms. International Institute of Tropical Agriculture, Nigeria.

Otim-Nape, G. W., Thresh, J. M., \& Shaw, M. W. (1997). The effects of cassava mosaic virus disease on yield and compensation in mixed stands of healthy and infected cassava. Annals of Applied Biology, 130(3), 503-521. https://doi.org/10.1111/j.1744-7348.1997.tb07678.x

Pei, Y. L., Shi, T., Li, C. P., Liu, X. B., Cal, J. M., \& Liuang, G. X. (2014). Distribution and pathogen identification of cassava brown leaf spot in China. Genetics and Molecular Research, 13(2), 3461-3473. https://doi.org/10.4238/2014.April.30.7

Pelczar, M. J., Pelczar, R. M., Kelman, A., \& Shurtleff, M. C. (2020). Plant disease. Encyclopedia Britannica. Retrieved from https://www.britannica.com/science/plant-disease

Powbunthorn, K., Abudullakasium, W., \& Unartngam, J. (2012). Assessment of the severity of brown leaf spot disease in cassava using image analysis. The International Conference of the Thai Society of Agricultural Engineering.

Takatsu, A., Fukuda, S., \& Perrin, S. (1978). Epidemiological aspects of bacterial blight of cassava in Brazil. Proceedings of an International Symposium on Disease of Tropical Food Crops (pp.141-150).

Teri, J. M., Thurston, H. D., \& Lozano, J. C. (1978). Effect of brown leaf spot and Cercospora leaf blight on cassava production. Tropical Agriculture, 57(3), pp.239-243.

Terry, E. R., \& Hahn, S. K. (1980). The effect of cassava mosaic disease on growth and yield of a local and an improved variety of cassava. International Journal of Pest Management, 26(1), 34-37. https://doi.org/ $10.1080 / 09670878009414280$

Thresh, J. M., Fargette, D., \& Otim-Nape, G. W. (1998). The viruses and virus diseases of cassava in Africa. African Crop Science Journal, 2, 459-78.

Tsatsia, H., \& Jackson, G. (2010). Cassva brown leaf spot. PestNet. Retrieved March 30, 2021, from http://www.pestnet.org/fact_sheets/cassava_brown_leaf_spot_095.htm

\section{Appendix A}

\section{Disease Incidence Calculation}

Table A1. Percentage disease incidence of cassava brown leaf spot at Mani road village

\begin{tabular}{llll}
\hline Village 1 & \multicolumn{3}{c}{ Mani road } \\
\cline { 2 - 4 } Plant No. & Number of leaves per plant & Number of infected leaves per plant & \% Disease incidence \\
\hline 1 & 38 & 12 & $31.6 \%$ \\
2 & 40 & 13 & $32.5 \%$ \\
3 & 33 & 12 & $36.4 \%$ \\
4 & 35 & 14 & $42.9 \%$ \\
5 & 36 & 12 & $36.1 \%$ \\
6 & 40 & 18 & $47.5 \%$ \\
7 & 42 & 18 & $47.6 \%$ \\
8 & 40 & 12 & $30 \%$ \\
9 & 22 & 9 & $40.9 \%$ \\
10 & 20 & 7 & $35 \%$ \\
11 & 25 & 10 & $40 \%$ \\
12 & 24 & 9 & $37.5 \%$ \\
13 & 28 & 12 & $46.4 \%$ \\
14 & 30 & 11 & $40 \%$ \\
15 & 28 & 15 & $53.5 \%$ \\
16 & 40 & 14 & $37.5 \%$ \\
17 & 40 & 18 & $50 \%$ \\
18 & 41 & 19 & $48.8 \%$ \\
19 & 38 & 14 & $42.1 \%$ \\
20 & 40 & 11 & $30 \%$ \\
\hdashline Total (average) & $\mathbf{3 4}$ & $\mathbf{1 3}$ & $\mathbf{3 8 . 2} \%$ \\
\hline
\end{tabular}


Table A2. Percentage disease incidence of cassava brown leaf spot at Boca village

\begin{tabular}{llll}
\hline Village 2 & \multicolumn{2}{c}{ Boca } \\
\cline { 2 - 4 } Plant No. & Total no. of leaves per plant & Total no. of leaves infected per plant & \% Disease incidence \\
\hline 1 & 35 & 13 & $37.1 \%$ \\
2 & 30 & 12 & $40 \%$ \\
3 & 31 & 18 & $58.1 \%$ \\
4 & 28 & 7 & $25 \%$ \\
5 & 27 & 11 & $40.7 \%$ \\
6 & 40 & 17 & $42.5 \%$ \\
7 & 28 & 11 & $39.3 \%$ \\
8 & 38 & 9 & $23.7 \%$ \\
9 & 35 & 8 & $22.9 \%$ \\
10 & 31 & 13 & $41.9 \%$ \\
11 & 32 & 12 & $37.5 \%$ \\
12 & 45 & 17 & $37.8 \%$ \\
13 & 44 & 19 & $43.2 \%$ \\
14 & 36 & 9 & $25 \%$ \\
15 & 33 & 13 & $39.4 \%$ \\
16 & 30 & 12 & $40 \%$ \\
17 & 20 & 7 & $35 \%$ \\
18 & 22 & 7 & $31.8 \%$ \\
19 & 30 & 9 & $30 \%$ \\
20 & 37 & 16 & $43.2 \%$ \\
- Total (Average) & $\mathbf{3 3}$ & $\mathbf{1 2}$ & $\mathbf{3 6 . 4 \%}$ \\
\hline & & & \\
\hline
\end{tabular}

Table A3. Percentage disease incidence of cassava brown leaf spot at Anuve village

\begin{tabular}{llll}
\hline Village 3 & \multicolumn{2}{c}{ Anuve } & \\
\cline { 2 - 4 } Plant No. & Total no. of leaves per plant & Total no. of leaves infected per plant & \% Disease incidence \\
\hline 1 & 34 & 16 & $47.1 \%$ \\
2 & 28 & 12 & $42.9 \%$ \\
3 & 34 & 15 & $44.1 \%$ \\
4 & 42 & 23 & $54.8 \%$ \\
5 & 38 & 14 & $36.8 \%$ \\
6 & 40 & 17 & $42.5 \%$ \\
7 & 35 & 15 & $42.9 \%$ \\
8 & 26 & 11 & $42.3 \%$ \\
9 & 27 & 7 & $25.9 \%$ \\
10 & 29 & 7 & $24.1 \%$ \\
11 & 38 & 9 & $23.6 \%$ \\
12 & 36 & 9 & $25 \%$ \\
13 & 39 & 22 & $56.4 \%$ \\
14 & 42 & 20 & $47.6 \%$ \\
15 & 41 & 26 & $63.4 \%$ \\
16 & 28 & 10 & $35.7 \%$ \\
17 & 34 & 15 & $44.1 \%$ \\
18 & 34 & 17 & $50 \%$ \\
19 & 35 & 15 & $42.9 \%$ \\
20 & 40 & 20 & $50 \%$ \\
\hline Total (Average) & $\mathbf{3 5}$ & $\mathbf{1 5}$ & $\mathbf{4 2 . 9 \%}$ \\
\hline
\end{tabular}

\section{Copyrights}

Copyright for this article is retained by the author(s), with first publication rights granted to the journal.

This is an open-access article distributed under the terms and conditions of the Creative Commons Attribution license (http://creativecommons.org/licenses/by/4.0/). 